\title{
Passa-se uma engenhoca ou como se faziam transações com terras, engenhos e crédito em mercados locais e imperfeitos (freguesia de Campo Grande, Rio de Janeiro, séculos XVIII e XIX)
}

\author{
'Engenhocas' to sell! \\ or lands, sugar mills and credit's trade in local \\ and imperfect markets (Campo Grande civil parish, \\ Rio de Janeiro, Brazil, XVIII-XIX centuries )
}

MANOELA PEDROZA

Mestre em História, Doutora em Ciências Sociais Professora Universidade Federal do Rio de Janeiro Departamento de História, IFCS, UFRJ, Largo de São Francisco, 1, sala 204, Centro, CEP 20051-070 Rio de Janeiro - RJ - Brasil manoelap@gmail.com

RESUMO A questão central deste artigo é perceber como as hierarquias sociais e as políticas específicas do Antigo Regime nos Trópicos se refletiram em estratégias concretas, e compreender as engrenagens locais de um mercado imperfeito. Analisaremos as escolhas e trajetórias de agentes envolvidos em transações com terras, engenhos e concessão de crédito na freguesia de Campo Grande, no correr do século XVIII até o início do XIX, cuja especificidade foi conseguirem reproduzir sua condição senhorial. Metodologicamente, partimos da microanálise e compusemos redes sociais locais que sustentaram as estratégias dos agentes em questão. Propomos que as rendas criadas a partir das vendas a prazo, os vínculos pessoais

* Artigo recebido em: 21/07/2008. Aprovado em: 28/01/2010. 
entre compradores-credores-vendedores-devedores nas vendas dos engenhos e a sobreposição de vínculos de dependência locais foram fatores que possibilitaram a acumulação econômica e a reprodução ampliada da condição senhorial.

Palavras-chave engenhos de açúcar, mercado de terras, crédito local

ABSTRACT Using the concept of 'Ancien Régime on the Tropics', this article aims to investigate how social hierarchies and politics in Brazil, during the 18th century, reflected into concrete local strategies. Our objective is to understand the gadgets of an imperfect market, based on agents' choices who were all involved in lands, sugar mills and credit commercial transactions in the Campo Grande civil parish, in the Rio de Janeiro. All agents had gotten to reproduce its extended senhorial condition. Our methodology is based on microanalysis, so we composed local social nets we guest had supported the agents' strategies in question. We consider strategies to achieve long term incomes; bonds between purchaser, creditor, salesman and debtors (both involving sugar mills commercial transactions); the overlapping of dependence bonds by strategic exchanges created by sugar mill masters among consanguineous, matrimonial and fictitious relatives had been factors that made possible the economic accumulation and the extended reproduction of the master condition.

Keywords sugar mills, land market, local credit

Muito já foi pesquisado sobre os meandros da reprodução da economia colonial brasileira. Em termos bastante amplos, a partir do século XVIII verifica-se a tendência de subordinação da agroexportação aos interesses mercantis, estes últimos intimamente dependentes da economia e da cultura política dos colonizadores. Em outras palavras, no contexto colonial, um grupo bastante restrito de homens se aproveitou de condições privilegiadas no campo da política - mercês, cargos, regalias, concessões, monopólios -como base de seu enriquecimento. Suas fortunas acumuladas no âmbito mercantil, mas com mentalidade de Antigo Regime, foram mais tarde reinvestidas em terras e engenhos, perpetuando o sistema colonial. Segundo João Fragoso, "o 'homem bom' antecedeu o senhor de engenho e não o inverso". ${ }^{1}$ A relação historicamente construída entre poder e economia colo-

1 FRAGOSO, João Luís Ribeiro. A nobreza da República: notas sobre a formação da primeira elite senhorial do Rio de Janeiro (séculos XVI e XVII). Topoi: Revista do Programa de Pós-Graduação em História da UFRJ. Sete Letras, v.1, p.45-122, 2000. 
niais foi consubstanciada nos engenhos de açúcar, considerados símbolos da plantation colonial brasileira.

Mas essas linhas gerais não nos esclarecem a respeito dos mecanismos concretos utilizados por aqueles agentes para atingirem seus objetivos, nem o lastro que essas estratégias podem ter tido em contextos locais. Em uma pesquisa densa e inaugural, Giovanni Levi insistiu sobre o fato de que o mercado de terras não era impessoal nas sociedades rurais tradicionais, mas regido por lógicas particulares, onde cada transação conseguia seu preço pela relação pessoal entre o vendedor e o comprador. ${ }^{2}$ Lançado o desafio, vários historiadores se dedicaram a inserir o mercado fundiário e o preço da terra nas relações sociais mais amplas que o condicionariam, desdobrando, reforçando ou negando as hipóteses de Levi. ${ }^{3}$

Para Gérard Béaur, a conjuntura mais ampla impunha um nível geral de preços que as relações de força locais podiam, pouco a pouco, corrigir. As relações familiares, geográficas, ou sociais agiam conjuntamente e criavam sistemas de preços mais complexos do que a média. Em um mercado local de terras francês do século XVIII, Béaur concluiu que as relações entre parentes faziam crescer a oferta mas, fora do quadro local, não tinham maior eficácia. Já as relações de vizinhança não tinham mais importância que as relações entre grupos sociais com possibilidades financeiras diferentes, que era o fator que mais pesava no preço auferido pela terra. Segundo Bernard Derouet, seria preciso ver a parentela como uma forma de "conciliar a mobilidade real da terra, de dar coesão a parceiros privilegiados (os parentes) e, ao mesmo tempo, de fornecer uma racionalidade genuinamente econômica a essas transações". ${ }^{4}$ Portanto, hoje existe um consenso de que não é possível analisar o mercado de terras na época moderna como algo impessoal, e mais que, ao menos para a Europa, não parece pertinente a oposição entre parentela e mercado.

Béaur analisou também as formas híbridas de transmissão de propriedade entre familiares. No caso de co-herdeiros de um bem, frente ao fato de nem sempre ser possível indenizar em dinheiro aqueles que vendiam sua parte da herança ao sucessor preferencial, existiram inúmeros

2 LEVI, Giovanni. Terra e strutture familiari in una comunità piemontese del '700. Quaderni Storici. Bologna, Itália, Università degli Studi, Urbino/Istituto di Storia e Sociologia, v.11, n.33, 1976.

3 AUGUSTINS, Georges. Esquisse d'une comparaison des systèmes de perpétuation des groupes domestiques dans les sociétés paysannes européennes. Archives Européennes de Sociologie, v.23, n.1, p.39-72, 1982; BARTHELEMY, Tiphaine. Les modes de transmission du patrimoine: synthèse des travaux effectués depuis quinze ans par les ethnologues de la France. Études Rurales, v.110-112, (La terre: Succession et héritage), p.195-212, 1988; BÉAUR, Gérard. Prezzo della terra, congiuntura e società alla fine del XVIII secolo: I'esempio di un mercato della Beauce. Quaderni Storici, Bologna/Urbino, Università degli Studi/lstituto di Storia e Sociologia, v.22, n.65, 1987; BÉAUR, Gérard. Foncier et crédit dans les societés préindustrielles: des liens solides ou des chaînes fragiles? Annales HSS, ano 49, n.6, p.1411-1428, 1994; SERVAIS, Paul. De la rente au crédit hypothécaire en période de transition industrielle: stratégies familiales en région liégeoise au XVIII siècle. Annales HSS, ano 49, n.6, p.13931410, 1994.

4 DÉROUET, Bernard. Parenté et marché foncier a l'époque moderne: une reinterprétation. Annales HSC, n.2, p.337368,2001 . 
contratos de pagamento em forma de renda anual ou de cessão de bens, que serviam para indenizar um parente de uma parte da herança que ele poderia reclamar. Os direitos sucessórios não eram puramente vendidos, mas negociados por meio de contrapartidas imobiliárias consentidas pelo beneficiário. Além disso, inúmeras transações entre pais e filhos - vendas a fundo perdido, vendas em troca de pensão vitalícia, demissão em favor de um filho, doação gratuita, avanço da legítima para dote - ficavam a meio caminho entre a venda, a doação e a sucessão. Todas essas podem ser vistas como formas híbridas de transmissão de propriedade complementares ao processo sucessório.

Gérard Béaur nos fez atentar para o papel de crédito nas diversas formas de transmissão de propriedade. Para ele, a maior parte das vendas de terras eram forçadas, fruto de necessidade de crédito ou para quitar uma dívida. Alguns contratos previam que o vendedor tivesse o direito de recomprar o bem vendido pelo mesmo preço que o vendeu no prazo de 5 anos, mesmo que, na maioria dos casos, o vendedor fosse incapaz de recuperar sua terra. Já no caso das anticreses, o vendedor, também devedor, cedia seus bens ao seu credor para lhe pagar uma dívida, e sua terra fica como que provisoriamente hipotecada, mas a situação tendia a se tornar definitiva. Em ambos os casos, o comprador fez de um direito de usufruto temporário uma situação permanente.

Béaur concluiu que o mercado fundiário era um espaço partido porque, em torno de um núcleo duro de vendas totais, anônimas e duráveis, gravitava toda uma série de contratos mistos, que faziam parte, ao mesmo tempo, do mercado de terras e de outras formas de transmissão. Situados na fronteira entre o sistema feudal, o sistema sucessório, o sistema judiciário, o mercado de dinheiro, o mercado dos aluguéis e das trocas, esses contratos vão de encontro à homogeneidade de transações simples. Por isso, o mercado fundiário não podia ser isolado de outras formas de transmissão. ${ }^{5}$

A questão central deste artigo é justamente perceber como as hierarquias sociais e as políticas específicas do Antigo Regime nos Trópicos se refletiram nas estratégias locais, precisamente no que diz respeito ao mercado de terras, engenhos e crédito. Nos perguntamos de que forma essas transações de engenhos envolvendo clientes e parentes se relacionariam com a reprodução senhorial.

A freguesia de Campo Grande nos pareceu um recorte espacial exemplar para a análise desse processo, por duas razões. A primeira é que sua ocupação pela plantation escravista, na forma de engenhos de açúcar, esteve totalmente inserida no segundo período de reformulação das estratégias econômicas senhoriais, após 1730, e também completamente

5 BÉAUR, Gérard. Prezzo della terra, congiuntura e società alla fine del XVIII secolo: l'esempio di un mercato della Beauce. 
esgotada já no início do século XIX. Portanto, foi durante aproximadamente cem anos que alguns agentes se empenharam em criar um patrimônio em terras, fábricas e escravos na região, algo que pode ser acompanhado no correr de três gerações. A segunda razão para a escolha dessa freguesia é que esse grupo de senhores locais não possuía o mesmo status político da verdadeira "nobreza da terra" carioca, radicada há mais tempo em seus engenhos na freguesia de Irajá. Possuindo menos recursos políticos, econômicos e relacionais, os senhores de Campo Grande tiveram de lidar mais sabiamente com recursos locais, algo que também pode ser facilmente constatado através das transações patrimoniais e matrimoniais entre parentes, vizinhos e compadres.

Chegamos a esses indivíduos, basicamente, através da leitura de listagens governamentais e episcopais do final do século XVIII e início do $\mathrm{XIX} .{ }^{6} \mathrm{~A}$ partir dessas listagens pudemos confeccionar uma tabela com as transferências dos engenhos de açúcar da freguesia de Campo Grande, entre 1777 e 1813 (Tabela 1). Dentre os inúmeros nomes citados, alguns nos chamaram a atenção pela recorrência (demonstrando a estabilidade da fábrica açucareira no seio de uma mesma família senhorial) e outros pela fugacidade (demonstrando a intensa atividade do mercado de terras e engenhos). Esses senhores foram mais bem conhecidos no cotejo com outro grupo de fontes, dentre as quais se destacam alguns processos depositados no Arquivo Nacional. ${ }^{7}$ Para a análise das redes de crédito locais, foi utilizada, sobretudo, a lista de dívidas ativas no inventário post mortem do senhor de engenho Manoel Antunes Susano. ${ }^{8}$ Para compormos as redes locais dos senhores, foram utilizados alguns livros de registros de batismos de livres e escravos das Freguesias de Campo Grande e Irajá, em amostragens entre o período de 1740 e $1820 .^{9}$

6 O relatório feito pelos mestres de campo de 1777 foi transcrito por: FRÓES, José Nazareth de Sousa e GELABERT Odaléa Ranauro Ensenat. Rumo ao Campo Grande: por trilhas e caminhos. Rio de Janeiro: s.e., 2004, p.47; e VÁRZEA, Affonso. Engenhos dentre Guanabara-Sepetiba. Brasil Açucareiro, ano XIII, 1945; e o de 1797 por: LAMEGO, Alberto Ribeiro. Os engenhos de açúcar nos recôncavos do Rio de Janeiro, em fins do século XVII. Brasil Açucareiro, 1942. O rol de desobriga número 15 foi transcrito também por José Nazareth Fróes, mas seus originais foram extraviados. Ver também Arquivo da Cúria da Arquidiocese do Rio de Janeiro (ACARJ). VP 01, 1794. Livro das visitas pastorais feitas pelo Monsenhor Pizarro no ano de 1794. Freguesia de Campo Grande, f. 24v a $29 \mathrm{v}$.

7 Sobre o engenho do Mendanha, ver Rio de Janeiro. Arquivo Nacional (AN). Fundo Processos SDJ. Diversos, ano 1823, n.510, caixa 1145. Sobre o do Viegas, ver processo anexado em AN. Fundo Inventários. Nome: Manoel Antunes Susano, ano 1783, notação 2, caixa 3629. Sobre engenho Bangu, ver AN. Fundo Processos SDJ. Diversos, autos de Força Nova, ano 1823, notação 322, caixa 1121. Sobre Engenho de Cabuçu, ver AN. Maço 1746, n.4248.

8 AN. Fundo Inventários. Nome: Manoel Antunes Susano, ano 1783, notação 2, caixa 3629.

9 Os registros de batismos aqui analisados fazem parte de uma amostragem maior que tabulou a totalidade dos seguintes livros, depositados no ACRJ: Batismos de Livres: AP-337 (Irajá, 1751-1759), AP-285 (Campo Grande, 1752-1759), AP-290 (Campo Grande, 1835-1849), AP-291 (Campo Grande, 1844 - 1849), AP-294 (Campo Grande, 1874-1880), AP-295 (Campo Grande, 1880-1883); Batismos de Escravos: AP-343 (Irajá, 1740-1759) e AP-285 (Campo Grande, 1750-1759). 
Tabela 1 - Transmissões de Engenhos em Campo Grande (1777-1813)

\begin{tabular}{|c|c|c|c|c|}
\hline LOCAL / DATA & 1777 & 1794 & 1797 & 1813 \\
\hline BANGU & $\begin{array}{l}\text { Gregório de Moraes } \\
\text { Castro Pimentel, } \\
\text { capitão* }\end{array}$ & $\begin{array}{l}\text { José Correia, } \\
\text { sargento-mor (filho) }\end{array}$ & $\begin{array}{l}\text { Ana Bangu (filha ou } \\
\text { esposa) }\end{array}$ & $\begin{array}{l}\text { Manoel Joaquim } \\
\text { de Souza*, major } \\
\text { (inventariante) }\end{array}$ \\
\hline CABUÇU & $\begin{array}{l}\text { Úrsula Martins (viúva } \\
\text { de Marcos Cardoso } \\
\text { dos Santos) }\end{array}$ & $\begin{array}{l}\text { Úrsula Martins (viúva } \\
\text { de Marcos Cardoso } \\
\text { dos Santos) }\end{array}$ & $\begin{array}{l}\text { José Cardoso dos } \\
\text { Santos (filho) }\end{array}$ & $\begin{array}{l}\text { Herdeiros de José } \\
\text { Cardoso dos Santos }\end{array}$ \\
\hline CAMPINHO & & & $\begin{array}{l}\text { Francisco Pereira } \\
\text { Lemos, padre }\end{array}$ & $\begin{array}{l}\text { Francisco Pereira } \\
\text { Lemos, padre }\end{array}$ \\
\hline CAPOEIRAS & $\begin{array}{l}\text { Ana Maria de Jesus } \\
\text { (viúva de João Pereira } \\
\text { Lemos) }\end{array}$ & $\begin{array}{l}\text { José Antunes Susano } \\
\text { filho, capitão (genro) }\end{array}$ & $\begin{array}{l}\text { José Antunes } \\
\text { Susano filho, capitão } \\
\text { (genro) }\end{array}$ & $\begin{array}{l}\text { José Antunes Susa- } \\
\text { no e João Antunes } \\
\text { Susano (netos) }\end{array}$ \\
\hline COQUEIROS & $\begin{array}{l}\text { José Antunes Susano } \\
\text { pai }\end{array}$ & $\begin{array}{l}\text { Vitória Barreto e } \\
\text { filhos (viúva de José } \\
\text { Antunes Susano pai) }\end{array}$ & $\begin{array}{l}\text { Manoel Antunes Su- } \\
\text { sano, alferes (filho) }\end{array}$ & $\begin{array}{l}\text { Manoel Antunes } \\
\text { Susano, alferes } \\
\text { (filho) }\end{array}$ \\
\hline GUANDU & $\begin{array}{l}\text { Francisco da Silva } \\
\text { Sena }\end{array}$ & $\begin{array}{l}\text { Francisco da Silva } \\
\text { Sena }\end{array}$ & $\begin{array}{l}\text { Francisco da Silva } \\
\text { Sena }\end{array}$ & $\begin{array}{l}17 \text { pequenos } \\
\text { proprietários }\end{array}$ \\
\hline INHOAÍBA & $\begin{array}{l}\text { Antônio Antunes } \\
\text { Susano* }\end{array}$ & $\begin{array}{l}\text { José Antunes Susano } \\
\text { filho, capitão }\end{array}$ & $\begin{array}{l}\text { José Antunes Susa- } \\
\text { no (filho ou neto?) }\end{array}$ & $\begin{array}{l}\text { José Antunes } \\
\text { Susano e Manoel } \\
\text { Antunes Susano } \\
\end{array}$ \\
\hline JUARI & $\begin{array}{l}\text { Vitorino Rodrigues } \\
\text { Rosas }\end{array}$ & $\begin{array}{l}\text { Bernardo José Dan- } \\
\text { tas, tenente (compra) }\end{array}$ & \begin{tabular}{|l} 
Bernardo José \\
Dantas, tenente
\end{tabular} & \begin{tabular}{|l} 
Bernardo José \\
Dantas, tenente
\end{tabular} \\
\hline LAMARÃO & $\begin{array}{l}\text { Mariana Nunes de } \\
\text { Souza e herdeiros }\end{array}$ & $\begin{array}{l}\text { José da Silva Álva- } \\
\text { res, capitão }\end{array}$ & $\begin{array}{l}\text { José da Silva Álva- } \\
\text { res, capitão }\end{array}$ & $\begin{array}{l}\text { José da Silva } \\
\text { Álvares, capitão }\end{array}$ \\
\hline $\begin{array}{l}\text { MATO DA } \\
\text { PACIÊNCIA }\end{array}$ & $\begin{array}{l}\text { João Carvalho } \\
\text { de Vasconcelos, } \\
\text { Cirurgião-mor }\end{array}$ & $\begin{array}{l}\text { João Francisco, capi- } \\
\text { tão (por compra) }\end{array}$ & $\begin{array}{l}\text { João Francisco, } \\
\text { negociante (foreiro } \\
\text { dos carmelitas) }\end{array}$ & \\
\hline MENDANHA & $\begin{array}{l}\text { Francisco Caetano } \\
\text { de Oliveira Braga, } \\
\text { capitão }\end{array}$ & $\begin{array}{l}\text { Antônio Couto da } \\
\text { Fonseca, padre } \\
\text { (compra) }\end{array}$ & $\begin{array}{l}\text { Antônio Couto da } \\
\text { Fonseca e José } \\
\text { Álvares de Azevedo }\end{array}$ & $\begin{array}{l}\text { Antônio Garcia } \\
\text { Durão (herdeiro de } \\
\text { Francisco Garcia do } \\
\text { Amaral) }\end{array}$ \\
\hline PIRAQUARA & & $\begin{array}{l}\text { Maria Inácia (viúva } \\
\text { de Manoel Fernandes } \\
\text { Barata) }\end{array}$ & $\begin{array}{l}\text { Maria Inácia (viúva } \\
\text { de Manoel Fernan- } \\
\text { des Barata) }\end{array}$ & $\begin{array}{l}\text { João e Sebastião } \\
\text { Fernandes Barata, } \\
\text { tenente }\end{array}$ \\
\hline RETIRO & & $\begin{array}{l}\text { José Correia, } \\
\text { sargento-mor }\end{array}$ & Ana Bangu & Emerenciana Maria \\
\hline RP CABUÇU & & $\begin{array}{l}\text { Marcos Cardoso dos } \\
\text { Santos (filho) }\end{array}$ & $\begin{array}{l}\text { Marcos Cardoso dos } \\
\text { Santos (filho) }\end{array}$ & $\begin{array}{l}\text { Marcos Cardoso } \\
\text { dos Santos (filho)* }\end{array}$ \\
\hline TINGUI & & & & $\begin{array}{l}\text { Joaquim Pereira de } \\
\text { Lemos }\end{array}$ \\
\hline VIEGAS & $\begin{array}{l}\text { Antônio Garcia do } \\
\text { Amaral e Mano- } \\
\text { el Freire Ribeiro } \\
\text { (compra) }\end{array}$ & $\begin{array}{l}\text { Jerônimo Pinto } \\
\text { Ribeiro }\end{array}$ & $\begin{array}{l}\text { Francisco Garcia do } \\
\text { Amaral }\end{array}$ & $\begin{array}{l}\text { Manoel Antunes } \\
\text { Susano, alferes* }\end{array}$ \\
\hline
\end{tabular}

Fontes: Relatórios de 1777 e 1797, Visita Paroquial de 1794 e Desobriga de 1813. 
Finalmente, este trabalho lida com alguns conceitos que merecem ser explicitados. O primeiro é o de estratégia, como o produto do senso prático, o "sentido do jogo" que se adquire desde a infância, participando das atividades em um contexto social e historicamente definido. ${ }^{10}$ Faremos também constantemente referência a famílias senhoriais. No caso brasileiro há deslizamentos no sentido original do termo senhorial, derivado da feudalidade européia, dado que, na colônia, poucas são as famílias realmente nobres e mesmo os mais ricos e poderosos nunca tiveram prerrogativas feudais como a isenção do pagamento de impostos e a total autonomia jurisdicional. Mesmo assim, continuamos a lidar com um sistema em que a política, e não o mercado, geria a economia; e onde a acumulação dependia de fatores provenientes do ordenamento jurídico e social da metrópole portuguesa, considerados arcaicos ou feudais. ${ }^{11}$

Manteremos, portanto, o adjetivo senhorial no contexto colonial para indicar uma família na qual algum descendente masculino se tornou, em algum momento, senhor de engenho, ${ }^{12}$ fato que dependia estreitamente de relações no campo da política que permitissem a acumulação de capital, a obtenção de terras e de mão-de-obra compulsória, e a manutenção de privilégios comerciais. Além disso, o adjetivo deve também comportar a dimensão simbólica das hierarquias sociais do Antigo Regime nos Trópicos, que se explicitavam por meio de inúmeros rituais de deferência cotidianos que afirmavam as prerrogativas desses senhores e seu séquito em relação ao povo comum. Por isso, como ratificava um jesuíta da época, "o ser Senhor de Engenho é título a que muitos aspiram, porque traz consigo o ser servido, obedecido e respeitado de muitos". ${ }^{13}$

Usamos o conceito de Antigo Regime nos Trópicos como uma fissura do modelo que se configurava na metrópole ${ }^{14}$ adaptado a um contexto diverso do Rio de Janeiro do século XVIII (de enriquecimento rápido e grande dependência de nobres pobres em relação aos novos comerciantes ricos), mas que funcionava com os mesmos velhos instrumentos. ${ }^{15}$ Para os objetivos deste artigo, a característica do Antigo Regime nos Trópicos mais importante a reter será a de um mercado imperfeito, conceito expresso por

10 BOURDIEU, Pierre. Das regras às estratégias. In: Coisas ditas. São Paulo: Brasiliense, 1990.

11 FLORENTINO, Manolo e FRAGOSO, João. O arcaísmo como projeto: mercado atlântico, sociedade agrária e elite mercantil no Rio de Janeiro (1790-1840). Rio de Janeiro: Livraria Sette Letras, 1996.

12 FRAGOSO, João Luís Ribeiro A nobreza da República: notas sobre a formação da primeira elite senhorial do Rio de Janeiro (séculos XVI e XVII).

13 ANTONIL, André João. Cultura e opulência do Brasil por suas drogas e minas. $3^{a}$ ed. Belo Horizonte/ São Paulo: Itatiaia/Edusp, 1982 [1711]. (Coleção Reconquista do Brasil).

14 FRAGOSO, João Luís Ribeiro; BICALHO, Maria Fernanda e GOUVÊA, Maria de Fátima. O antigo regime nos trópicos: a dinâmica imperial portuguesa (séculos XVI-XVIII). Rio de Janeiro: Civilização Brasileira, 2001.

15 Para uma discussão sobre códigos, visão de mundo e concepção política do Antigo Regime português, importados para o Brasil com a colonização, ver HESPANHA, António Manuel e XAVIER, Ângela Barreto. A representação da sociedade e do poder. In: MATTOSO, José. (org.) História de Portugal. Lisboa: Estampa, 2006. 
Witold Kula ${ }^{16}$ e utilizado por João Fragoso ao analisar as especificidades sócio-econômicas da colônia. Fragoso percebeu que a dinâmica dos negócios coloniais dependia de elementos externos à economia, tais como o parentesco ou a política. ${ }^{17}$ Para ele, os indivíduos teriam oportunidades econômicas diferentes se tivessem acesso aos cargos da administração pública. Logo, esse mercado voltado à reprodução da plantation agroexportadora teria um caráter "restrito e imperfeito", já que marcado por relações sociais de produção não-capitalistas.

No correr deste trabalho buscaremos comprovar uma hipótese, que se refere ao que apelidamos de atalhos da ascensão sócio-econômica tupiniquim. Segundo pesquisas de João Fragoso, pode-se afirmar que as famílias que descendem dos ministros e oficiais constituem o esteio da elite senhorial do Rio de Janeiro, pois que são as que possuem, no correr dos Seiscentos, o maior número de senhores de engenho, a maior estabilidade no tempo e a maior capacidade de gerar outras famílias senhoriais. Em suas palavras,

fato que é mais reforçado, ainda, quando nos lembramos da delicada teia de relações de parentesco, via casamentos, que desde cedo eles começariam a tecer. Em suma, a combinação de todas estas circunstâncias daria àqueles homens uma posição bastante confortável no mando e, portanto, nos destinos da nova colônia. ${ }^{18}$

A partir dos nossos estudos de caso gostaríamos de comprovar que a reprodução social dos senhores-de-engenho em Campo Grande, ainda no final do século XVIII e início do XIX, continuava se dando através dessa particular combinação de circunstâncias: monopólio de cargos públicos, obtenção de concessões da metrópole, estratégias de nobilitação, de transmissão de bens e estruturas familiares típicas do Antigo Regime nos Trópicos. Nesse contexto, relações comerciais ou de mercado não estavam ausentes, mas foram constantemente ressignificadas a partir de uma visão particular de mundo e dos negócios. Em suma, a análise de alguns casos de agentes envolvidos com transações de crédito, terras e engenhos nos comprovaria a determinação das relações de mercado por outras estratégias de ascensão e reprodução social tidas como mais arcaicas. ${ }^{19}$

Vamos aos casos.

16 KULA, Witold. Problemas y métodos de la historia económica. Barcelona: Peninsula, 1977. (Serie Universitária Historia, Ciencia Sociedad).

17 FRAGOSO, João Luís Ribeiro. Homens de grossa aventura: acumulação e hierarquia na praça mercantil do Rio de Janeiro (1790-1830). $2^{2}$ ed. Rio de Janeiro: Civilização Brasileira, 1998, p.399.

18 FRAGOSO, João Luís Ribeiro. A nobreza da República: notas sobre a formação da primeira elite senhorial do Rio de Janeiro (séculos XVI e XVII).

19 FLORENTINO, Manolo e FRAGOSO, João. O arcaísmo como projeto. 


\section{Dizimeiro Marcos Cardoso dos Santos e o engenho de Cabuçu}

O engenho de Cabuçu era o maior da freguesia, com 87 escravos em 1777 e 108 em 1797. Segundo a Tabela 1, neste último ano ele deixava de ser administrado por Úrsula Martins, viúva do dizimeiro Marcos Cardoso dos Santos, e passara a seu filho José. Retomaremos um pouco da história patrimonial desse engenho. Segundo José de Nazareth Fróes,,$^{20} \mathrm{em} 1611$, sobejos de uma antiga sesmaria abandonada que conteriam as terras de Cabuçu foram dados a Tomé de Alvarenga. Em 1696, seus herdeiros venderam estas terras a Manoel Paredes da Costa, que acrescentou a estas mais 500 braças de terras compradas e, em 1699, vendeu todas "e todo sertão que Ihe tocar" a Manoel Pacheco Calheiros. O genealogista Rheingantz nos forneceu a informação de que, ao menos até 1704, Manoel Pacheco Calheiros era senhor daquele engenho. ${ }^{21} \mathrm{Em} 1744$, o engenho foi a leilão, com o consentimento dos herdeiros de Calheiros. Ele foi arrematado por Antônio Vieira de Miranda, que o vendeu quatro anos depois para Marcos Cardoso dos Santos. ${ }^{22}$ A partir de 1744 a família Cardoso dos Santos se estabeleceu em Cabuçu, onde seus herdeiros permaneceram ao menos até o final do século XIX. ${ }^{23}$ Portanto, por mais de cem anos a sesmaria de Cabuçu esteve sujeita a concessões, abandonos, reconcessões, heranças, diversas vendas, além de acréscimos e execuções por dívidas.

Em 1750, temos notícia de que Marcos Cardoso dos Santos era arrematador dos dízimos da cidade. ${ }^{24}$ Segundo João Fragoso, os arrematadores de impostos quase sempre eram negociantes, residentes no Brasil ou brasileiros, que usaram de seus muitos cabedais para arrematar uma fonte de renda preciosa do Estado português. Portanto, o posto de dizimeiro indica tanto a fortuna de Marcos Cardoso dos Santos quanto sua provável posição de negociante e sua proximidade com a "economia do bem comum" da administração colonial. ${ }^{25}$

20 AN. Maço 1746, n.4248 (Processo Cabuçu, f.28).

21 RHEINGANTZ, Carlos Grandmasson. Primeiras famílias do Rio de Janeiro. Rio de Janeiro: Livraria Brasiliana, 1965 Tomo II, p.54.

22 FRIDMAN, Fania. Donos do Rio em nome do rei: uma história fundiária da cidade do Rio de Janeiro. $2^{\mathrm{a}}$.ed. Rio de Janeiro: Jorge Zahar Editor, 1999, p.302; FRÓES, Jose Nazareth de Sousa e GELABERT, Odaléa Ranauro Ensenat. Rumo ao Campo Grande, p.247; RHEINGANTZ, Carlos Grandmasson. Primeiras famílias do Rio de Janeiro.

23 Relação dos engenhos da Freguesia de Campo Grande de acordo com o Almanack Laemmert de 1883 ver: FRÓES, José Nazareth de Souza e GELABERT, Odaléa Ranauro Enseñat. Rumo ao Campo Grande, p.247.

24 Precisamos esclarecer que em Portugal e suas colônias o rei tinha a prerrogativa do padroado, ou seja, era ele quem cobrava o dízimo que depois seria repassado à igreja católica. Mas como o estado moderno não tinha estrutura burocrática para arrecadar os próprios impostos, leiloava para terceiros, pelo valor mínimo do que pensava arrecadar. Essa estrutura de contratar impostos seria transferida para todas as colônias, inclusive o Brasil.

25 João Fragoso define por economia do bem comum, ou economia da República, um conjunto de bens e serviços no Antigo Regime português que encerravam uma forma particular de apropriação do excedente social, pois que eram concedidos, pelo Senado e/ou pelo rei, para apenas alguns eleitos. Tal privilégio era exercido na condição de monopólio ou de semi-monopólio, portanto, os demais moradores/súditos que ousassem interferir em tais monopólios, seriam punidos pela lei. Cf. FRAGOSO, João Luís Ribeiro. A nobreza da República: notas sobre a formação da primeira elite senhorial do Rio de Janeiro (séculos XVI e XVII). 
Figura 1: Herdeiros do dizimeiro Marcos Cardoso dos Santos (1650-1760)
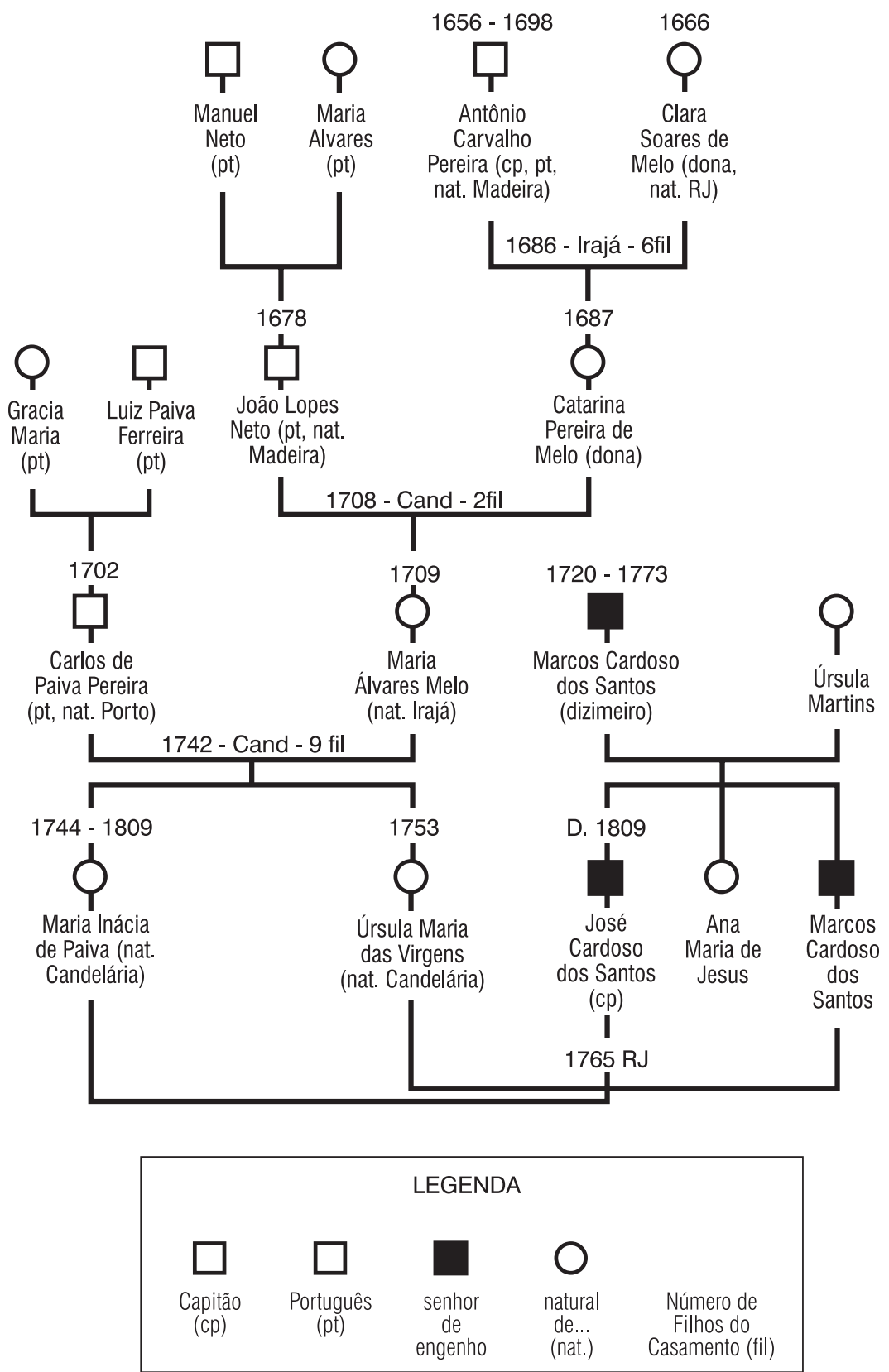

Fontes: LAMEGO, Alberto Ribeiro. Os engenhos de açúcar nos recôncavos do Rio de Janeiro, em fins do século XVII; FRAGOSO, João Luís Ribeiro. Capitão Manuel Pimenta Sampaio, senhor do Engenho do Rio Grande; AN. Fundo Inventários. Origem: Juízo de Órfãos. Nome: José Cardoso dos Santos. Ano: 1822, caixa 3763, n.5; Nome: Marcos Cardoso dos Santos, inventariante. Origem: Juízo Municipal, Revista Cível, Ano: 1824, caixa 3763, n.22; Origem: Juízo de Órfãos. Maço 3, n.34; Fundo Processos SDJ Diversos. Ação de Libelo. Ano 1819. N.4204, maço 1744; ACMARJ AP-286. 
Ainda em vida, vários homens como Marcos reinvestiram as rendas auferidas por contratos e negócios em terras e engenhos, atividades econômicas mais seguras e de mais status. ${ }^{26}$ Nota-se a rapidez da inversão de capitais na fazenda de Cabuçu que, recém-adquirida pelo dizimeiro, já figurava em 1750 como possuidora do maior plantel da freguesia, mantendo-se nesse topo pelos próximos cinquenta anos.

João Fragoso analisou detidamente o processo de formação da primeira elite senhorial do Rio de Janeiro no século XVII, a transformação de um grupo de oficiais do Rei em senhores de engenho, possível graças à conquista do território e à prática costumeira do Rei conceder mercês aos súditos que lhe prestavam serviços. ${ }^{27}$ Com o passar do tempo e as mudanças econômicas, essa "nobreza da terra" criou estratégias de reprodução social bastante complexas. Uma delas passava pelo casamento dos filhos para selar alianças e atingir objetivos diferentes, fossem com negociantes, com senhores menos nobres, até com lavradores pobres vizinhos aos engenhos.

Seguindo esse script, Marcos e sua mulher parecem ter sido bastante cuidadosos ao arranjar o casamento dos seus dois filhos. Escolheram como sogra dona Maria Álvares de Mello. As fontes, nesse caso, caminham contra nós, pela raridade e imprecisão, mas, articulando penosamente as poucas peças encontradas - como os títulos de pais e sogros, locais e datas de nascimento e casamento - julgamos que Dona Maria tenha sido descendente direta de conquistadores, transformados, gerações mais tarde, na "nobreza da terra" carioca, ciosamente radicada em seus engenhos de açúcar na freguesia de Irajá. Ela era dona e neta de capitão português casado em Irajá em 1686, onde provavelmente recebeu terras e instalou sua família. ${ }^{28}$

É nesse contexto que podemos entender o casamento das duas filhas de dona Maria, na mesma cerimônia, no ano de 1765, com os dois filhos de Marcos Cardoso dos Santos: Marcos (filho) com Úrsula Maria das Virgens, de apenas 12 anos, e José com Maria Inácia de Paiva, de 21 anos. Esse seria um típico exemplo das estratégias matrimoniais da elite da colônia no século XVIII. ${ }^{29}$

Mas essa mesma cerimônia pode ser interpretada pelo outro lado dessa relação. O casamento duplo, entre irmãos, nos parece uma tentativa do dizimeiro Marcos Cardoso dos Santos de cimentar boas relações com as gentes da antiga nobreza colonial. Negociante que se transformava em senhor de engenho, ele precisava criar relações "para o alto", ou seja, com

26 FRAGOSO, João Luís Ribeiro. Homens de grossa aventura, p.399

27 FRAGOSO, João Luís Ribeiro. A nobreza da República: notas sobre a formação da primeira elite senhorial do Rio de Janeiro (séculos XVI e XVII).

28 RHEINGANTZ, Carlos Grandmasson. Primeiras famílias do Rio de Janeiro, p.321.

29 FRAGOSO, João Luís Ribeiro. A nobreza vive em bandos: a economia política das melhores famílias da terra do Rio de Janeiro (século XVII). Tempo - Revista do Departamento de História da UFF, Niterói, v.8, n.15, p.11-35, 2003. 
pessoas de reconhecido prestígio que já ocupassem postos de destaque na colônia.

Pelo inventário do filho José, falecido em 1809, onde foram listados os bens deixados por seus pais, Marcos e Úrsula, podemos ter uma idéia do que eles conseguiram acumular em vida: aproximadamente ${ }^{30}$ cinco mil braças de testada de terras em Cabuçu e Sepetibinha. Além disso, havia mais de uma centena de escravos na fazenda Cabuçu, o maior plantel da freguesia.

Além de suas estratégias matrimoniais, gostaríamos de perceber de que forma os objetivos dessa família se refletiriam nas redes sociais tecidas em nível local. Nos registros de batismos de escravos da freguesia, de 1750, vimos que Marcos Cardoso nem recebia padrinhos escravos de outros senhores em sua senzala, nem permitia que seus escravos transcendessem sua fazenda. Ele mesmo e sua esposa também não batizavam filhos dos homens livres da região, possivelmente vizinhos. ${ }^{31}$ Nesse período, a família não priorizou a criação de laços com outras famílias locais, ricas ou pobres, antigas ou recém-chegadas.

Em síntese, o dizimeiro Marcos Cardoso dos Santos foi, ou melhor, buscou ser um elemento da nobreza da terra: arrematou contrato do governo da colônia, através do qual amealhou imenso patrimônio fundiário e em escravos. Marcos e Úrsula quiseram manter com mão de ferro cercas, filhos, noras e netos, prescrevendo comportamentos matrimoniais, econômicos e políticos bastante restritivos. Suas estratégias matrimoniais para os filhos miraram para "fora" da freguesia, sobretudo para o estabelecimento de relações verticais com famílias de mais status.

Nesse fim de século XVIII, auge da pujança do engenho de Cabuçu, os netos do dizimeiro começaram a se casar. Infelizmente, dispomos de quase nenhuma fonte para conhecer melhor suas escolhas nesse campo. Sabemos apenas que Marcos (neto) casou-se com dona Cecília Rosa de Oliveira, filha de tenente, natural de Angra dos Reis; Angélica com João Vieira Borges, ajudante de almoxarife; e Rita foi deserdada pelo pai. Se estivesse calculando o casamento dos filhos como o seu foi calculado, José Cardoso dos Santos deve ter aprovado o casamento de Marcos com Cecília, "dona" vinda de fora, assim como sua esposa e sua cunhada; também o de Angélica com João Vieira Borges, "funcionário público" como seu pai; e lamentado - ou se enfurecido - com o de Rita com um "joão-ninguém" local. De fato, sobre o tenente Teixeira da Fonseca, pai dos seis filhos de Rita, temos apenas pistas esmaecidas de que tenha sido oriundo de uma das tantas famílias de lavradores pobres que havia na freguesia.

30 Dizemos aproximadamente porque na briga entre herdeiros as mesmas datas de terras tiveram várias vezes sua área total diminuída, chegando a 3.282 braças, em 1820. Ver questão em AN. Fundo Inventários. Nome: Angélica Maria Ignácia de Paiva, inventariante. Origem: Juízo de Órfãos, Apelação de Partilha, ano 1826, n.34, maço 3, f. 253,336 e 583 ss

31 Cf. ACARJ AP-285, várias páginas. 
Depois de acompanhar durante cinqüenta anos o ciclo de vida da família Cardoso dos Santos, podemos caracterizar em linhas gerais o seu comportamento, digamos assim, econômico. Marcos parece amalgamar, em sua trajetória pessoal, o processo pelo qual passava o Rio de Janeiro no século XVIII, quando a cidade passara a ser um dos pólos do império português. Podemos ver que ele optou por reinvestir a sua fortuna, acumulada possivelmente graças aos circuitos monopolísticos da "economia do bem comum" da colônia, em terras, engenhos e escravos. Nesse campo, usou dos meios de acumulação típicos de um mercado imperfeito (a arrematação de contratos) para atuar ativamente no mercado de terras, escravos e engenhos do seu tempo, como pode ser verificado na longa lista do seu patrimônio inventariado.

Ao lado de sua preocupação permanente com o crescimento e manutenção de seu patrimônio, suas estratégias matrimoniais para os filhos miraram para fora da freguesia, sobretudo para o estabelecimento de relações verticais com famílias de mais status. Estratégias de nobilitação que caminharam ao lado, aparentemente sem contradições, de práticas econômicas no mercado da época.

\section{Capitão Antônio Garcia do Amaral e o engenho do Viegas}

O antigo engenho da Lapa passou a se chamar "do Viegas" por ter pertencido à família Viegas, que construiu sua capela em 1725. Essa família era a típica "nobreza da terra" tupiniquim: descendente de conquistadores quinhentistas que, dentre seus vários ramos, dividiam entre si casamentos estratégicos, patentes, negócios, engenhos e vários cargos da administração colonial. ${ }^{32}$ Por mecanismos que desconhecemos, esse engenho passou da família Viegas para Antônio Garcia do Amaral, que consta como seu senhor no relatório de 1777. Antônio Garcia do Amaral vivia em Irajá, onde se situava o engenho, a partir da década de 1740, pois apareceu em registros de batismo dessa freguesia. Nesses registros, Antônio não indicou ter nem um grande plantel nem status, haja vista sua pouca aparição como proprietário de escravos e também como padrinho. ${ }^{33}$

32 Na virada do século XVII para o XVIII, herdeiros, capitães e donas da família Viegas estavam instalados em inúmeros engenhos em Irajá. Até meados do século XVIII, Antonio Soares Viegas e Luis Gago da Câmara Silveira Viegas eram ligados a cargos e à vida administrativa da cidade. Cf. RHEINGANTZ, Carlos Grandmasson. Primeiras famílias do Rio de Janeiro; AGCRJ. Coletânea de pesquisas realizadas no setor 3 Histórico do Arquivo Geral - 2 HD do Estado da Guanabara durante os anos de 1956 a 1960. AN. Fundo Inventários. Falecido: José Antunes Susano. Inventariante: Francisca Maria da Conceição. Notação 39, caixa 3610. s-d. e FRAGOSO, João Luís Ribeiro. Capitão Manuel Pimenta Sampaio, senhor do Engenho do Rio Grande, neto de conquistadores e compadre de João Soares, pardo: notas sobre uma hierarquia social costumeira: Rio de Janeiro, 1700 - 1760. In: XXIII Simpósio Nacional da ANPUH. São Leopoldo, 2007. (mimeo)

33 ACARJ Livro de Registro de batismos de livres da freguesia de Irajá, f.93-verso e 103-frente; Livro de registro de escravos da freguesia de Irajá (AP 343, de 1740-1759), f. 97-frente. 
Figura 2: Engenho do Viegas, histórico patri-matrimonial

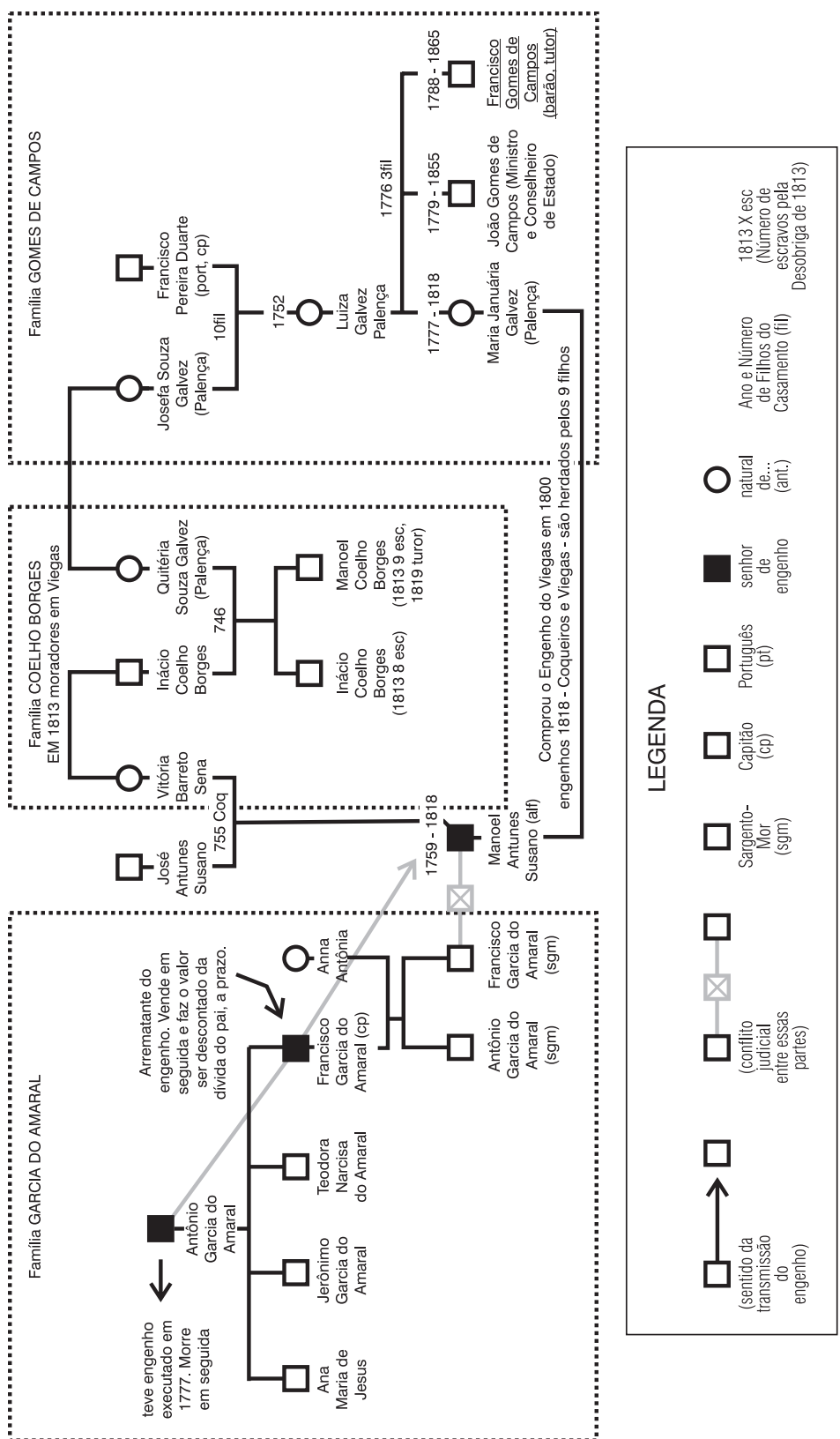

Fontes: AGCRJ. Coletânea de pesquisas realizadas no setor 3 do Histórico do Arquivo Geral - 2 HD do Estado da Guanabara durante os anos de 1956 a 1960; AN. Fundo Inventários. Nome: Manoel Antunes Susano, Ano 1783, Notação 2, caixa 3629. (processo movido por outro Manoel); AP286 (1767 a 1811); AN. Fundo Inventários. Falecidos: Manoel Antunes Susano e Maria Januária Galvez Palença. Inventariante: João Gomes de Campos, ano 1819, notação 77, caixa 3629; LAMEGO, Alberto Ribeiro. Os engenhos de açúcar nos recôncavos do Rio de Janeiro, em fins do século XVII e FRÓES, José Nazareth de Sousa e GELABERT, Odaléa Ranauro Ensenat. Rumo ao Campo Grande 
Dada a ausência completa de documentação a respeito dessa transferência e a rarefação de fontes sobre os moradores do engenho da Lapa, que nos permitam afirmar com mais segurança as relações entre ambas as famílias, Viegas e Garcia do Amaral, durante o século XVIII, pode-se apenas aventar algumas hipóteses. João Fragoso considera que o engenho do Viegas tenha passado aos Garcia do Amaral pelo casamento de um moço Amaral com uma moça Viegas, provavelmente Antônio Nunes do Amaral, casado em $1721 \mathrm{com}$ Mariana Barbosa de Soberal, por essa via senhor do engenho São Bernardo e falecido sem filhos. ${ }^{34}$

De nossa parte, tendo em vista que Antônio Garcia do Amaral não parecia ter cabedais suficientes para comprar esse engenho, e reforçando a hipótese de João Fragoso, julgamos que essa transferência tenha se dado através do que chamamos de "casamentos desiguais". Seriam alianças entre famílias de cabedais desiguais, geralmente senhores e lavradores livres ligados ao mesmo engenho, precedidas pela aproximação no mundo do trabalho, pelo compadrio de batismo e por uma ascendência comum que, por vezes, eram acionados para consagrar casamentos entre os filhos desses compadres, quase sempre vizinhos e primos entre si. ${ }^{35} \mathrm{Se}$, pelo lado das famílias senhoriais, esses casamentos serviam para colocar os filhos excluídos da herança em sítios vizinhos, ${ }^{36}$ pelo lado dos lavradores eles permitiram alguns casos de ascensão sócio-econômica e mesmo de nobilitação. De qualquer forma, por força das leis e costumes da época relativos à meação e sucessão dos bens do casal, ambas as famílias de origem dos cônjuges passavam, do casamento em diante, a estar imbricadas na transmissão do patrimônio senhorial em questão. Por isso, a nosso ver, mais relevante do que detectar qual foi exatamente o(a) Garcia do Amaral que casou-se com um(a) herdeir(a) do engenho do Viegas, seria reter que a antiga proximidade de ambas as famílias em torno do engenho deve ter tornado propício o estabelecimento dessa seqüência de relações voluntárias que culminaram com a transferência de propriedade do engenho para Antônio Garcia do Amaral, por volta de 1777.

Antônio Garcia do Amaral teve esse engenho executado em praça por seus credores, em 1777. Ele morreu logo em seguida, e suas dívidas - não totalmente pagas pela execução do engenho - recaíram sobre seus herdeiros. Até aí, apenas a confirmação da crise pela qual passaram os engenhos mais antigos, desde o final do século XVIII.

\footnotetext{
34 Comunicação pessoal à autora. Sem data.

35 PEDROZA, Manoela. Capitães de bibocas: casamentos e compadrios construindo redes sociais originais nos sertões cariocas (Capela de Sapopemba, freguesia de Irajá, século XVIII). Topoi: Revista do Programa de PósGraduação em História da UFRJ, Rio de Janeiro, v.9, n.17, p.67-92, 2008.

36 PEDROZA, Manoela. Transmissão de terras e direitos de propriedade desiguais nas freguesias de Irajá e Campo Grande (Rio de Janeiro, 1740-1856). Revista de História, São Paulo, n.160, p.323-362, 2009.
} 
Acontece que quem arrematou o engenho, por 18.000 cruzados, foi o filho do executado, capitão Francisco Garcia do Amaral, que o vendeu logo em seguida, a prazo, por 45.000 cruzados, para Manoel Freire Ribeiro, nome que também apareceria como senhor no relatório de 1777. A cláusula interessante dessa venda foi que as parcelas do pagamento do engenho "foram aplicadas aos credores do pai d''lle vendedor, executado, até serem pagos de suas dívidas segundo a convenção que fizeram com elle vendedor". ${ }^{37}$ Ou seja, à medida que a dívida da compra do engenho fosse sendo sanada por seus compradores, as dívidas da família Garcia do Amaral, devedores e vendedores ao mesmo tempo, também seriam pagas.

A cadeia de pagamentos cruzados foi só aumentando: o engenho foi vendido em 1789 pelos herdeiros de Manoel Freire Ribeiro a Jerônimo Pinto Ribeiro, (provavelmente um aparentado, se levarmos em conta o sobrenome), que constava como seu senhor pelo relatório de 1794. Este Jerônimo o vendeu ao alferes Manoel Antunes Susano, em 1800. Este último, numa atitude inesperada, sanou o remanescente das dívidas para com os herdeiros Garcia do Amaral - três contos de réis (1.081,25 libras) - em 1813. Assim, foram quase 50 anos durante os quais as prestações do engenho sustentaram a família de seus devedores. Nesse como em outros casos, a parentela e os amigos foram a fonte por excelência de crédito e de parceiros no mercado. Além disso, tanto compradores quanto vendedores, no momento da venda, colocaram em contato uma numerosa rede de atores ligados entre si por fluxos de crédito.

Mas esse não era o único investimento senhorial da família Garcia do Amaral. Soubemos pelas listagens oficiais que, em 1797, outro Antônio Garcia do Amaral era senhor do engenho do Calundu, na freguesia de Jacutinga, vizinha ao norte de Campo Grande. ${ }^{38} \mathrm{E}$, através de outro documento judicial, conhecemos um terceiro Antônio Garcia do Amaral, capitão-mor, que comprou o engenho do Mendanha, na mesma freguesia de Campo Grande, em 1812. Essa última compra, também a prazo, envolveu os herdeiros do capitão-mor num complicado processo de cobrança de dívidas pelos antigos donos do engenho do Mendanha, semelhante ao que aconteceu com o engenho do Viegas, vinte anos antes. ${ }^{39}$ Só que agora os Garcia do Amaral eram os compradores, inserindo-se na cadeia longa dos que desembolsavam valores irrisórios à vista, mas herdavam a obrigação de saldar a dívida com os vendedores. Em síntese, atuando no mercado de engenhos e crédito hipotecário da época, esses Antônios perpetuaram

37 AN. Fundo Inventários. Nome: Manoel Antunes Susano ano 1783, notação 2, caixa 3629. (ressaltamos que o processo de venda do engenho do Viegas e os problemas de seu pagamento foi movido por outro Manoel Antunes Susano, que não é o falecido nesse inventário, mas se encontra, por engano, dentro desse documento citado). 38 LAMEGO, Alberto Ribeiro. Os engenhos de açúcar nos recôncavos do Rio de Janeiro, em fins do século XVII.

39 AN. Fundo Processos SDJ Diversos ano 1823, n.510, caixa 1145. 
a condição senhorial de sua família através da ajuda de parentes e redes de crédito muito complexas. Como interpretar essas transações?

Nesse caso, seria preciso entender a confecção de redes de crédito locais baseadas na venda de fábricas a prazo. Gérard Béaur provou, em sua pesquisa, que no Antigo Regime francês apenas 15\% a 25\% do valor da terra circulava efetivamente em dinheiro, no momento de sua venda. Já que a venda não mobilizava uma poupança prévia do comprador, a maior parte do valor permanecia na forma de crédito, quitado a longo prazo, sendo a venda apenas o evento gerador de uma longa cadeia de financiamento. Nós encontramos a ligação entre mercado de terras e crédito quando percebemos que boa parte do pagamento proveniente de uma venda de terra se fará para saldar dívidas anteriores ou para se desvencilhar de um bem carregado de dívidas. Um contrato de venda de terra implicava, na realidade, em uma parte paga em dinheiro, outra parte na transferência de dívidas antigas, outra parte na da criação de novas dívidas. ${ }^{40}$

O dinheiro necessário para que o comprador desse início à transação provinha, quase sempre, da mobilização de algum crédito de sua parentela. No caso desta não ser capaz de provê-lo, eram acionados agiotas ou credores profissionais conhecidos pela família ou recrutados por algum intermediário, através, por exemplo, de relações clientelísticas. Assim, mesmo a pequena parcela do pagamento em espécie pode ser considerada artificial, já que, na imensa maioria das vezes, não provinha de uma poupança prévia, e sim de um crédito externo, ou seja, do endividamento frente a terceiros. Béaur nos lembra também que, quanto maior o valor do bem, maior a complexidade das condições de pagamento e da parte financiada, que chegavam quase ao paroxismo, diante, por exemplo, da venda de enormes senhorias.

A arrematação do engenho pelo filho do senhor endividado e sua venda em seguida (para um conhecido? Não sabemos...) teriam sido um artifício para, através do recebimento das prestações, não somente sanar a dívida maior do pai (que recairia sobre os herdeiros), mas, com os excessos, prover uma renda segura para os mesmos. Portanto, essas vendas representaram tanto a transferência real da propriedade quanto um meio de obter renda fixa em longo prazo.

Não seria coincidência que Antônio Garcia do Amaral tivesse seu engenho executado por dívidas em 1777, que houvesse outro Antônio Garcia do Amaral listado como senhor do engenho do Calundu, na freguesia de Jacutinga, no relatório de 1797, ${ }^{41}$ e que um dos filhos de Francisco Garcia do

40 BEAUR, Gérard. Foncier et crédit dans les societés préindustrielles: des liens solides ou des chaînes fragiles? Annales HSS, ano 49, n.6, p.1411-1428, 1994.

41 LAMEGO, Alberto Ribeiro. Os engenhos de açúcar nos recôncavos do Rio de Janeiro, em fins do século XVII. 
Amaral, o capitão que arrematara o engenho endividado do pai e o vendera a prazo, se tornasse também senhor de engenho, a partir de 1812. ${ }^{42}$

E será que o endividamento ou as origens duvidosas de um engenho fazia diferença para o prestígio local do seu senhor? Julgamos que não. A família Garcia do Amaral nos chama a atenção para o fato de que todos esses compradores, que nunca pagavam o valor da mercadoria à vista e muito menos suas parcelas a prazo, se julgavam absolutamente legítimos proprietários, tinham patentes públicas e eram respeitados em suas paragens. A própria viúva do alferes Manoel Antunes Susano, em 1818, ao precisar de um avaliador dos engenhos do falecido marido, convocou o capitão Antônio Garcia do Amaral, senhor de engenho vizinho, para tal tarefa ${ }^{43}$ menosprezando a capacidade de outros avaliadores que não eram eles próprios senhores de engenho. O mesmo Antônio, três anos antes, ainda sargento, havia litigado com Manoel Joaquim de Souza, senhor dos engenhos de Bangu e Retiro, por se julgar no direito das terras que estavam na divisa entre os seus engenhos, e ganhou a causa. ${ }^{44} \mathrm{E}$ para provar a longevidade desse prestígio, em 1877, um século depois do engenho de seu trisavô ter sido executado, um quarto Antônio Garcia do Amaral estava na enxuta lista dos votantes da freguesia de Campo Grande. ${ }^{45}$

Podemos perceber que a família Garcia do Amaral tentou obstaculizar crises conjunturais que envolviam o patrimônio e o status de seus membros e aproveitar boas oportunidades mediante rolagem de dívidas, execuções arranjadas, transações entre parentes, cadeias de empréstimos, vendas a prazo, além das relações privilegiadas com pessoas poderosas, como os Viegas. Eles usaram estrategicamente os mecanismos permitidos a uma família senhorial da época, qual seja, de fazer dinheiro a partir de concessões gratuitas, cobrar mesmo devendo, manipular os circuitos de crédito e de poder como maneira de se recriar como família senhorial, no tempo e no espaço. Nossa hipótese é de que seja esse um dos vieses da economia política da elite da época, uma das facetas de seu comportamento econômico, pautada numa cultura que sancionava essas possibilidades, dentro de um contexto de mercado imperfeito.

Chegamos à conclusão que, passada a época de glória e chegado o momento de lidar com a crise, na segunda metade do século XVIII, os problemas e as falências de engenhos de açúcar deviam ser resolvidos em escala humana, por mecanismos concretos. Nesse sentido, fazia par-

42 AN. Fundo Processos SDJ Diversos, ano 1823, n.510, caixa 1145.

43 AN. Fundo Inventários. Falecidos: Manoel Antunes Susano e Maria Januária Galvez Palença. Inventariante: João Gomes de Campos' ano 1819. "otação 77, caixa 3629, f. 242.

44 AN. Fundo Processos SDJ Diversos. Autos de Força Nova ano 1823, n.322, caixa 1121.

45 AGCRJ, 68-3-73: Limites do Distrito Federal com o Estado do Rio de Janeiro. Nomes de eleitores e locais nas proximidades da Província do Rio de Janeiro constantes do livro de alistamento geral dos votantes da freguesia do Município Neutro precedido em 1877 de acordo com os arts. 58 e 60 das instruções que baixaram com o Dec. 6097 de 12 de janeiro de 1876. 
te da economia política dessa nobreza senhorial manipular a seu favor o mercado dos engenhos. O envolvimento da família Garcia do Amaral no mercado de crédito e engenhos da época realça o viés do "financiamento senhorial" em longo prazo e do encadeamento de compradores-credoresvendedores-devedores nas vendas dos engenhos, mostrando de que forma essas transferências encobriam uma forma de renda a longo prazo, que permitiu a reprodução da família senhorial, mesmo em outras paragens. O processo intermitente de vendas a prazo e os inúmeros imbróglios, processos, contestações e conflitos delas decorrentes, foi uma das táticas de reprodução das mesmas famílias senhoriais em locais diferentes, uma marca do processo seletivo de transferências patrimoniais que não chegou a permitir a ascensão de outro grupo social.

Mesmo assim, supomos que essa mágica não prescindiria das relações locais, funcionários de cartório ${ }^{46}$ e agiotas,${ }^{47}$ todos amigos ou conhecidos dos Garcia do Amaral, eles próprios relacionados com a família Viegas, notoriamente conhecida por possuir cadeiras no governo da colônia.

Também não foi por coincidência que esse engenho acabaria nas mãos do alferes Manoel Antunes Susano, neto de sesmeiro, que enriqueceu rapidamente também concedendo empréstimos aos devedores listados em seu inventário. Era essa a outra ponta das cadeias de crédito, que beneficiavam diretamente os que podiam dispor de liquidez para aumentar o próprio patrimônio, caso que veremos agora.

\section{Alferes Manoel Antunes Susano e as redes de crédito locais}

Devemos falar sucintamente do atual estado das pesquisas sobre crédito local em sociedades não capitalistas. Três especialistas nas redes de crédito de sociedades do Antigo Regime europeu são categóricos em afirmar a generalidade e a estruturação profunda do endividamento camponês, cujas conseqüências poderiam explicar muito daquela sociedade.

Partimos da premissa de que no Brasil colonial, como em outras sociedades predominantemente agrícolas, a maioria dos circuitos de crédito girava em torno da propriedade rural e de sua relação com o comércio. ${ }^{49}$

46 Sobre a atividade dos funcionários de cartório, ver especificamente LAFFONT, Jean L. Problèmes et méthodes d'analyse historique de l'activité notariale (XV-XIX siècles). Villeneuve d'Ascq : Presses Universitaires du Mirail, 1991

47 POSTEL-VINAY, Gilles. La terra a rate? Osservazioni sul credito e il mercato fondiario in Francia nel XIX secolo. Quaderni Storici.

48 Cf CHAYANOV, Maurice. Autoconsommation et marchés: Labrousse ou Le Roy Ladurie? In: BEAUR, Gérard. (org.) La terre et les hommes: France et Grande-Bretagne (XVII-XVIII siécle). Paris: Hachette Littératures, 1998, p.215-242; BEAUR, Gérard. Foncier et crédit dans les societés préindustrielles: des liens solides ou des chaînes fragiles? Annales HSS, ano 49, n.6, p.1411-1428, 1994; SERVAIS, Paul. De la rente au crédit hypothécaire en période de transition industrielle: stratégies familiales en région liégeoise au XVIII siècle. Annales HSS, ano 49, n.6, p.13931410, 1994

49 MALATESTA, Maria. Le aristocrazie terriere nell'Europa contemporanea. Roma: Editorial Laterza, 1999, p.199. (Quadrante laterza). 
Inúmeros trabalhos enfocaram o crédito agrícola na província do Rio de Janeiro, no correr do século XIX. Esses historiadores reiteram que o crédito à produção se fazia a partir de atores locais de posição econômica mais confortável e, longe de uma especialização do credor, suas operações caminhavam pari passu com outras, tais como negócios de compra de terras, fiado nos armazéns, açambarcamento da produção. A sobreposição dessas inúmeras funções garantia uma espécie de monopólio informal das operações de crédito, financiamento e comercialização nas mãos de poucos, além da formação de clientelas e circuitos de dependência nos campos da moral, da produção, da política e do comércio. De forma geral, se está lidando com um contexto em que o crédito à produção é sinônimo de endividamento do lavrador para com os grupos locais de maior liquidez. ${ }^{50}$

\section{Gráfico 1 - Devedores do Alferes Manoel Antunes Susano (1819)}

\section{DEVEDORES DE MANOEL ANTUNES SUSANO, ALFARES (1819)}

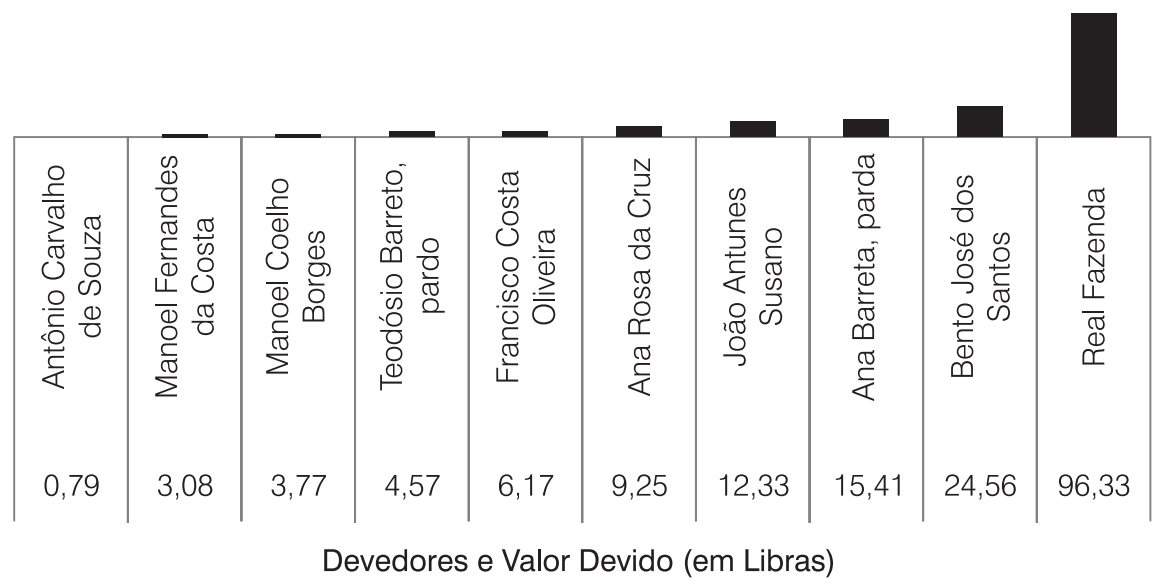

Fonte: AN. Fundo Inventários. Falecidos: Manoel Antunes Susano e Maria Januária Galvez Palença. Inventariante: João Gomes de Campos, ano 1819, notação 77, caixa 3629

50 FARIA, Sheila Siqueira de Castro. Terra e trabalho em Campos dos Goitacazes (1850-1920). Niterói: UFF, 1986 (História, Dissertação de mestrado); GRANER, Maria Paula. A estrutura fundiária do município de Araruama (1850-1920). Um estudo da distribuição de terras: continuidades e transformações. Niterói: UFF, 1985 (História, Dissertação de mestrado); MOTTA, Márcia Maria Menendes. Pelas "bandas d'além": fronteira fechada e arrendatários-escravistas em uma região policultora (1808 - 1888). Niterói: UFF, 1989 (História, Dissertação de mestrado); SAMPAIO, Antônio Carlos Jucá de. Magé na crise do escravismo: sistema agrário e evolução econômica (1850-1888). Niterói: UFF, 1994 (História, Dissertação de mestrado); SAMPAIO, Antônio Carlos Jucá de. O mercado carioca de crédito: da acumulação senhorial à acumulação mercantil (1650-1750). Estudos Históricos, Rio de Janeiro, v.29, 2002. 
Defendemos que, para as regiões coloniais menos lucrativas e, portanto, menos interessantes para os investimentos dos negociantes, os circuitos de produção parecem subsistir de créditos locais, já que nem inventários de senhores nem de lavradores apresentam dívidas ativas com negociantes da cidade. Vamos analisar relações sociais e políticas engendradas pelo endividamento local a partir de uma rede ego centrada de um grande credor, segundo método proposto por Ida Fazio..$^{51}$ Partimos do inventário de um grande senhor de engenho de Campo Grande, o alferes Manoel Antunes Susano, falecido em 1818 um pouco antes de sua esposa, Maria Januária Galvez Palença. Infelizmente, corroborando as dificuldades da nossa "microhistória tapuia", 52 sabemos que nossa amostra é muito diminuta. Mesmo assim, ela pode nos dar pistas de alguns processos sociais, no mínimo interessantes.

O alferes Manoel Antunes Susano foi o sucessor de seu pai, José Antunes Susano, como senhor do engenho dos Coqueiros. Mas tal privilégio teve seu preço e sua espera: ele casar-se-ia apenas depois da morte do pai, em 1796 (com 37 anos, acima da média da época, que era de 30 anos), permanecendo até então solteiro sob a autoridade paterna. José Antunes Susano e Vitória Barreto de Sena escolheram muito bem a esposa do filho sucessor. Maria Januária Galvez Palença não trouxe terras para a família, mas, por caminhos que não pudemos desvendar, apenas três anos após seu casamento o alferes Manoel comprou o engenho do Viegas, no qual estava estabelecida a parte pobre da família da mulher. O alferes morreu aos 59 anos, em 1818, legando a seus nove filhos um enorme patrimônio: 172 escravos em Coqueiros, 89 em Viegas, dois engenhos e suas terras, vários prédios, dinheiro, prata e ouro. Em suma, seu casal acumulara um patrimônio de 81 contos de réis (19.507,50 libras), o que era uma fortuna nos termos da época, comparada mesmo às dos grandes negociantes do Rio de Janeiro.

Qual o milagre para tanta liquidez? Temos poucas pistas sobre suas estratégias em vida para chegar a tão grande patrimônio, e nenhum livro de contabilidade. Sabemos apenas que as atividades de crédito não constituíam a principal ocupação do alferes. Apólices da Real Fazenda eram a maior parte das dívidas ativas: somavam 400.000 réis (96,33 libras). Depois, vinha a lista de pessoas físicas. O primeiro e maior devedor era Bento José dos Santos, cuja dívida de 102.000 réis (24,56 libras) foi perdoada pela esposa do alferes, antes de morrer. Também, pudera: Bento era casado com uma prima de Maria Januária e era compadre do credor desde 1792, com filho homônimo (Manoel). Suspeitamos, inclusive, que esse primeiro batizado tenha sido a aproximação do alferes com a família de sua futura esposa,

51 FAZIO, Ida. Trasmissione della proprietà, reti di credito e integrazione sociale in una comunità rurale siciliana dell'Ottocento.

52 O termo foi cunhado por João Fragoso, e me parece bastante apropriado no confronto com a qualidade de fontes primárias de que se vale a microhistória italiana. FRAGOSO, João Luís Ribeiro. Afogando em nomes: temas e experiências da história econômica. Topoi: Revista do Programa de Pós-Graduação em História da UFRJ, Rio de Janeiro, dezembro, 2002. 
com quem se casaria em 1796. O vínculo de Bento José dos Santos com seu credor era semelhante ao de Manoel Coelho Borges, outro devedor, para o qual o alferes havia passado um crédito de 15.660 réis (3,77 libras). Manoel era tio de sua esposa, administrador da Fazenda do Viegas há muitos anos, compadre do alferes desde 1798, com outro filho homônimo. Ainda dentro de sua parentela-clientela, pelo lado de sua família de origem, João Antunes Susano Ihe devia 51.200 réis (12,33 libras). Ele era sobrinho do alferes, padre, e administrava o engenho das Capoeiras desde 1813.

Nossos exemplos explicitam a relação do alferes Manoel Antunes Susano com sua rede de parentela, que incluía desde sitiantes pobres até o sobrinho senhor do engenho. Nesses casos, o fornecimento de crédito como "ajuda" podia estar voltado para a consolidação de relações que não almejavam o lucro em si, mas a manutenção da "qualidade" de sua casa, uma convivência pacífica ou até uma amizade sincera. A dívida poderia ser economicamente favorável ao devedor, como a do cunhado perdoado. Embora não tenhamos provas, inferimos que as contrapartidas se dessem também em bases não econômicas, como respeito, fidelidade, acordos de trabalho, contratos de meação, co-participação nos lucros, obrigações e dívidas morais.

A lista de devedores do alferes Manoel fora da sua parentela é bem mais imprecisa, já que não pudemos encontrar pistas da posição social da maior parte deles. Havia Anna Barreta, parda, que devia 64.000 réis (15,41 libras) de um crédito passado a seu genro; Anna Rosa da Cruz devia 38.400 réis (9,25 libras); Francisco da Costa Oliveira, filho de pai sem posses do local, devia crédito de 25.600 réis (6,17 libras); Teodósio Barreto, pardo, devia 18.970 réis (4,57 libras) pela compra de um cavalo; Manoel Fernandes da Costa pagava por um crédito de 12.800 réis (3,08 libras); e por fim, Antônio Carvalho de Souza pagava outro crédito de 3.280 réis $\left(0,79\right.$ libras). ${ }^{53}$ Neste conjunto emergem mais cinco lavradores da freguesia que contraíram pequenos créditos com o alferes. Dois, ao menos, sobrepunham à relação de credor-devedor com a de compadre, e outros dois explicitavam a marca de "pardos", sinal de clara desigualdade econômico-social entre as partes ${ }^{54}$. Todos pagavam juros de $6 \%$ ao ano.

53 AN. Fundo Inventários. Falecidos: Manoel Antunes Susano e Maria Januária Galvez Palença. Inventariante: João Gomes de Campos,ano 1819, notação 77, caixa 3629

54 Hebe Mattos observou que a categoria "pardo", típica do final do período colonial, tinha uma significação muito mais abrangente do que as de "mulato" ou "mestiço". "Pardo" foi inicialmente utilizado para designar a cor mais clara de alguns escravos, especialmente sinalizando para a ascendência européia de alguns deles, mas ampliou sua significação quando se teve que dar conta de uma crescente população para a qual não era mais cabível a classificação de "preto" ou de "crioulo", na medida em que estes tendiam a congelar socialmente a condição de escravo ou ex-escravo. A emergência de uma população livre de ascendência africana - não necessariamente mestiça, mas necessariamente dissociada, já por algumas gerações, da experiência mais direta do cativeiro consolidou a categoria "pardo livre" como condição lingüística para expressar a nova realidade, sem que recaísse sobre ela o estigma da escravidão, mas também sem que se perdesse a memória dela e das restrições civis que implicava. Ou seja, a expressão "pardo livre" sinalizará para a ascendência escrava africana; era a própria expressão da mancha de sangue. MATTOS, Hebe. Escravidão e cidadania no Brasil monárquico. Rio de Janeiro: Jorge Zahar, 2000. Sobre essa realidade ver também RUSSELL-WOOD, John. Escravos e libertos no Brasil colonial. Rio de Janeiro: Civilização Brasileira, 2005. 
Que o endividamento miúdo e contínuo seja o combustível do mercado de terras não é uma novidade. Na França, por exemplo, neste período também foram encontrados grandes personagens, sobretudo comerciantes rurais ou urbanos, que aproveitavam da necessidade generalizada de crédito e das vendas forçadas de terras endivididadas para aumentar seu patrimônio, já que dispunham de rara liquidez. ${ }^{55}$ Márcia Motta atestou o mesmo para os arrendatários da freguesia de São Gonçalo, no período de crise do escravismo: eles endividavam-se progressivamente com os proprietários de terra, donos dos portos, e com os pequenos negociantes locais para comprar o que não produziam. Esses negociantes faziam parte da classe dominante local e se inseriam nas parentelas de grandes famílias ${ }^{56}$

A lista de dívidas ativas do alferes Manoel Antunes Susano não é a de um credor profissional, nem de um negociante urbano, mas a de um rico senhor de engenho local. Ela aponta para dois grupos de devedores bem definidos. Por um lado, um ramo amplo que ia desde sua parentela mais empobrecida até seu sobrinho senhor de engenho, cujas reciprocidades não econômicas extrapolariam o valor formal do crédito. ${ }^{57}$ Por outro lado, havia um segundo grupo fora da parentela, possivelmente relacionado no mundo no trabalho e da vizinhança. Nesse segundo caso, estamos lidando com os empréstimos ligados às necessidades de subsistência dos lavradores, que possivelmente não seriam pagos em vida do devedor e serviam para ampliar as redes de clientela e subordinação do credor..$^{58}$

Os dados que apresentamos nos permitem aventar a hipótese de que, em nível local, alguns homens concediam créditos a vizinhos e parentes, no troca-troca cotidiano que envolvia relações de amizade e ajuda mútua, em redes que podiam sobrepor parentela, produção e negócios. Conrad Arensberg e Solon Kimball foram os que melhor formalizaram as relações, nem sempre evidentes, entre redes de crédito, poder, família e economia locais. Eles defenderam que, nas sociedades rurais, são as relações de dívida, traduzidas em relações de crédito, fundadas em laços de parentesco, e com natureza de obrigações, que constituem as redes de clientela, operantes por vínculos de dependência pessoal. Essas redes articulam as mediações com a economia comercial, expressando as relações pessoais e de reciprocidade nelas implicadas em termos de dívida monetária, contratualmente definida, mas de fato baseada em obrigações personalizadas e costumeiras. No limite em que se rompe essa reciprocidade costumeira e obrigatória, remete-se o litígio à esfera da lei, através do contrato. ${ }^{59}$

55 BEAUR, Gérard. Foncier et crédit dans les societés préindustrielles: des liens solides ou des chaînes fragiles?

56 MOTTA, Márcia Maria Menendes. Pelas "bandas d'além".

57 FAZIO, Ida. Trasmissione della proprietà, reti di credito e integrazione sociale in una comunità rurale siciliana dell'Ottocento.

58 FONTAINE, Laurence. Le reti del credito. La montagna, la città, la pianura: i mercanti dell'Oisans tra XVII e XIX secolo. Quaderni Storici. Bologna/Urbino: Università degli Studi/Istituto di Storia e Sociologia, v.23, n.68, 1988.

59 ARENSBERG, Conrad M; Kimball, Solon T. Family and community. In: Ireland. Ennis: CLASP Press, 2001 [1968]. 
A lista de devedores de Manoel Antunes Susano permite entrever redes sociais sobrepostas e densas: senhor, compadre, cunhado, tio, credor. Podemos perceber o quanto de moral, pessoal ou parental pode estar imbricado em contratos, processos judiciais, obrigações de pagamento e dívidas em haver. Sabendo que esse senhor, atuando confortavelmente nestas redes, chegou a possuir dois grandes engenhos e centenas de escravos em vida, podemos também inferir sobre a funcionalidade de tais transações para o enriquecimento e a acumulação. Como consequência, defendemos que a sobreposição de vínculos de dependência locais foi um dos fatores que possibilitaram a acumulação econômica.

Portanto, para além de um bom casamento, uma boa herança e tino para os negócios do açúcar, parece que encontramos uma explicação para o sucesso do alferes Manoel Antunes Susano na lista de dívidas ativas de seu inventário. Apenas no que estava registrado em 1818, seu casal não possuía sequer uma dívida em haver, mas havia passado cinco cartas de crédito. O valor era aparentemente baixo em face de seu patrimônio total (81 contos, ou 22.308,75 libras), mas uma pista de que o alferes pudesse ter enriquecido, ou sustentado sua riqueza, por outros meios, além dos engenhos.

Longe de ser uma exceção, a confecção de redes clientelares ligadas ao crédito foi um componente estrutural das sociedades agrárias pré-industriais. Somos levados a crer que, nessas sociedades, os laços que uniam credores e devedores seriam, em grande parte, as relações de parentela, poder e autoridade, vizinhança e trabalho. Portanto, encaramos que normas gerais e impessoais de crédito, numa dinâmica tradicional, podiam ser remodeladas e utilizadas em torno de uma rede de poder coerente e estável. ${ }^{60}$

\section{Conclusão}

A partir de 1730 ocorreu uma profunda transformação na vida econômica da colônia portuguesa na América, sentida diretamente no porto do Rio de Janeiro e seus arredores. Com a ascensão de um grupo de "negociantes de grosso trato" no controle dos principais meios de acumulação, a antiga "nobreza da terra", descendente dos primeiros conquistadores e solidamente estabelecida nos cargos da administração pública e em seus engenhos de açúcar, definhou economicamente. ${ }^{61}$ No entanto, sua perda de poder econômico não se reverteu diretamente em declínio político, social e mesmo cultural. Pelo contrário, esse grupo reforçou práticas sociais e econômicas estratégicas para a manutenção de certas prerrogativas.

60 DELILLE, Gérard. Le trop et le trop peu: capitaux et rapports de pouvoir dans un village de l'Italie du Sud (XVII-XVIII siècles). Annales HSS, v.49, n.6, p.1429-1442, 1994.

61 FRAGOSO, João Luís Ribeiro. Homens de grossa aventura, p.399. 
As estratégias da nobreza carioca para sua manutenção no poder passaram pelo controle do mercado imperfeito e dos cargos da administração pública, por um determinado sistema de transmissão de bens entre gerações, pela formação de redes clientelares via compadrio e por políticas matrimoniais bastante precisas. Esse conjunto, uma verdadeira economia política, Ihes conferia legitimidade social e poder de mando que os mantiveram no topo de uma hierarquia social costumeira durante todo o século XVII e XVIII.62

Foi com esse peculiar processo de reprodução senhorial local em meio à decadência econômica que lidamos nesse texto. Em Campo Grande, desde finais do século XVIII, as concessões diretas de terras (na forma de sesmarias) e a construção de novos engenhos de açúcar praticamente não existiram. Localmente, vimos que as estratégias econômicas puderam lançar mão tanto da cultura da época - corporativa e hierarquizante - e políticas econômicas coloniais - monopolistas, calcadas no privilégio e em relações pessoais com a governança - e de redes sociais que sustentaram as transferências de terras, engenhos e crédito em nível local.

A constante presença de senhores de engenho com patentes de capitão, tenentes ou padres nos mostra que o acesso a esses bens, mesmo que se desse por meio de compra, ainda era coisa restrita a poucos afortunados. ${ }^{63}$ Vimos também que novos senhores, mesmo que de origem diversa da "nobreza da terra", reproduziriam a dinâmica da plantation escravista colonial, passando por um mercado imperfeito, que comportava, além do investimento financeiro, relações sócio-econômicas personalizadas, sobreposição de vínculos de dependência material e moral, redes clientelísticas, informações privilegiadas, apadrinhamentos estratégicos.

As redes de crédito estritamente locais também indicaram o desinteresse dos intermediários típicos da cidade do Rio de Janeiro em atuarem naquela freguesia. Isso pode refletir a pouca expressividade da produção canavieira local, já em crise desde a ascensão da fronteira de Campos como a principal zona produtora da província, desde 1780. Por isso não encontramos nos inventários post mortem até 1830, menções a dívidas, comércio, ou relações sociais mais amplas. Portanto, cremos que tenham provindo dos senhores locais mais abastados as fontes de crédito da região.

Não podemos esquecer que as redes de crédito financiam direitos e, sobretudo no caso dos engenhos, o imenso status de ser senhor. Retomando Saint-Hilaire,

62 FRAGOSO, João Luís Ribeiro A nobreza vive em bandos: a economia política das melhores famílias da terra do Rio de Janeiro (século XVII).

63 FRAGOSO, João Luís Ribeiro. A nobreza da República: notas sobre a formação da primeira elite senhorial do Rio de Janeiro (séculos XVI e XVII). 
a posse de engenho de açúcar confere entre os lavradores do Rio de Janeiro como que uma espécie de nobreza. De um senhor de engenho só se fala com consideração e adquirir tal preeminência é a ambição geral. ${ }^{64}$

Em se tratando de posição tão cobiçada, parece ser compreensível que diversas estratégias, honestas ou não, fossem usadas para esse fim. Assim, expandindo a conclusão que João Fragoso já sustentara para a segunda metade do século XVII, ${ }^{65}$ defendemos que, ao menos para uma parte dos senhores de engenho de Campo Grande, durante todo o século XVIII e início do XIX, ingressar ou se manter na elite senhorial passava, concomitantemente, pelas vias tradicional e moderna.

64 SAINT-HILAIRE, Auguste de. Segunda viagem a São Paulo e quadro histórico da província de São Paulo Brasília: Senado Federal, Secretaria Especial de Editoração e Publicação, 2002. (Coleção O Brasil visto por estrangeiros).

65 "Ou seja, ainda na segunda metade do século XVII, ingressar na elite senhorial passava, majoritariamente, pela descendência ou casamento com netas ou bisnetas dos primeiros povoadores e, nesta condição, se teria mais facilmente o acesso às terras da coroa (...). Isto fica mais claro, por exemplo, quando lembramos que entre 1650 e 1700 mais de $40 \%$ dos sesmeiros eram descendentes (direta ou indiretamente) dos conquistadores. No mesmo período, $60 \%$ dos senhores de engenho descendiam ou estavam casados com moças daquele grupo." FRAGOSO, João Luís Ribeiro. A nobreza da República: notas sobre a formação da primeira elite senhorial do Rio de Janeiro (séculos XVI e XVII). 